\title{
Plant growth-promoting activity in bean plants of endophytic bacteria isolated from Echeveria laui
}

\author{
Anderson Emmera®, João Arthur dos Santos Oliveiraa®, Andressa Domingos Pollia®, Julio \\ Cesar Polonio ${ }^{a^{*}}$, Leonardo Hamamura Alvesa®, Cintia Zani Fávaro Polonio ${ }^{\circledR}$, João Lucio \\ Azevedob®, João Alencar Pamphilea(in memorian)® \\ a Universidade Estadual de Maringá, Maringá, 87020-900, Paraná, Brasil. *julioc_polonio@hotmail.com \\ b Programa de Pós-graduação em Biotecnologia Ambiental, Universidade Estadual de Maringá, Maringá, 87020-900, Paraná, Brasil
}

Received: January 23, 2020 / Accepted: May 3, 2021 / Published online: May 27, 2021

\begin{abstract}
Echeveria laui (Crassulaceae) is commonly commercialized due to its drought-tolerance capacity and to its rosette-shaped aesthetics. Since endophytes associated with plants from a dry or arid environment have scarcely been analyzed as yet, current research comprises the isolation of leaf endophytic bacteria from E. laui (one five-year-old and one two-year-old plants) investigating plant growth-promoting endophytic bacteria which may solubilize phosphate, fix nitrogen, produce exopolysaccharides/IAA and antagonize phytopathogens. Isolation by the maceration methodology provided a colonization rate of $1.98 \times 10^{9} \mathrm{CFU} \mathrm{g}^{-1}$ for the two-year-old plant and $1.14 \times 10^{10} \mathrm{CFU} \mathrm{g}^{-1}$ for the five-year-old one. All 40 isolates evaluated showed in vitro plant growth-promoting agent's abilities, with emphasis on EG04, ELG18, and ELP06. The capacity of the three best bacterial isolates were evaluated under greenhouse conditions in common and black bean (Phaseolus vulgaris $\mathrm{L}$.) plants. Based on the sequencing of the 16S rRNA region and phylogenetic analysis, the three endophytes were identified as Pantoea sp. (ELG04 and ELG18) and Erwinia sp. (ELP06). Under greenhouse conditions, statistically significant differences were found among the plants treated with the three endophytes when compared to control plants for fresh and dry shoot, root biomass and length.
\end{abstract}

Keywords: Endophytes, Erwinia sp., ornamental plant, Pantoea sp., Phaseolus vulgaris.

\section{Atividade de promoção de crescimento de plantas de feijão de bactérias endofíticas isoladas de Echeveria laui}

\begin{abstract}
Resumo
Echeveria laui (Crassulaceae) é comumente comercializada devido à sua capacidade de tolerância à seca e à sua estética em forma de roseta. Uma vez que endófitos associados a plantas de ambiente seco ou árido foram poucos explorados até então, este trabalho compreende o isolamento de bactérias endofíticas de folhas de E. laui (uma planta de cinco anos e uma de dois anos) investigando a capacidade de agente promotor do crescimento de plantas das bactérias endofíticas isoladas como solubilizar fosfato, fixar nitrogênio, produzir exopolissacarídeos/ AIA e antagonizar fitopatógenos. O isolamento pela metodologia de maceração proporcionou uma taxa de colonização de $1.98 \times 10^{9} \mathrm{UFC} \mathrm{g}^{-1}$ para a planta de dois anos e $1.14 \times 10^{10}$ UFC $\mathrm{g}^{-1}$ para a de cinco anos. Todos os 40 isolados avaliados mostraram habilidades do agente promotor de crescimento de plantas in vitro, com ênfase em EG04, ELG18 e ELP06. A capacidade dos três melhores isolados bacterianos foi avaliada em casa de vegetação em plantas de feijão preto e comum (Phaseolus vulgaris L.). Com base no sequenciamento da região $16 \mathrm{~S}$ rRNA e análise filogenética, os três endófitos foram identificados como Pantoea sp. (ELG04 e ELG18) e Erwinia sp. (ELP06). Em casa de vegetação, diferenças estatisticamente significativas foram encontradas entre as plantas tratadas com os três endófitos quando comparadas às plantas controle para o peso fresco e seco da parte aérea e raízes, bem como para o comprimento da raiz.
\end{abstract}

Palavras-chave: Erwinia sp., planta ornamental, Pantoea sp., Phaseolus vulgaris.

\section{Introduction}

Echeveria laui (Crassulaceae) is a plant that belongs to the genus Echeveria, with 150 species already described (Jo, Jang, Hong \& Parque, 2018). It is commonly commercialized due to its drought-tolerance capacity, rosette-shaped features and commercial value (Godeau et al., 2017). Studies report on the biological application of crude extracts of secondary metabolites from the genus Echeveria have been performed (López-Ângulo et al., 2016). In fact, microorganisms 
associated with plants from a dry or arid environment are still poorly studied. Studies on these still unknown endophytic communities may provide new knowledge on their taxonomy, ecology and biotechnological application in different areas (Bezerra, Azevedo \& Souza-Motta, 2017). Endophytes are known to colonize different plants living for at least part of their life cycle within their hosts (Adhikari \& Pandey, 2019).

The isolation and study of endophytic bacteria began in the 1940s and, even today, these microorganisms have been investigated from different aspects and with diverse approaches (Neetha, Sandesh, Kumar, Chidamamda \& Ujwal, 2019). There are only few reports on the isolation of endophytes associated with the Crassulaceae family, and the genus Echeveria has never been analyzed in this respect. The genus Sedum is one group of this family already reported upon with regard to the endophytic community (Ma et al., 2015).

Each plant has a characteristic endophytic microbiota for its development and maintenance, in which different factors directly or indirectly influence the endophytes' potential and diversity (Guo, Huang \& Wang, 2008). Enhancement of plant growth may occur through several mechanisms. Endophytes may assist in the solubilization of salts, fix nitrogen or produce phytohormones (Breda, Alves \& Reis, 2016). Endophytes have been proven to be an excellent strategy to improve agricultural performance by mitigating the negative effects of chemical pesticides (Sánchez-Crus et al., 2019).

Current research comprised the isolation of leaf endophytic bacteria from E. laui (a five-year-old plant and a two-year-old plant cultivated in a plant nursery) to investigate plant growthpromoting endophytic bacteria which may solubilize phosphate, fix nitrogen, produce exopolysaccharides/IAA and antagonize phytopathogens. The ability of the three best bacterial isolates under greenhouse conditions in common and black bean plants has also been assessed.

\section{Materials and Methods}

\section{Isolation of endophytic bacteria}

The plants were kindly provided by the Cactus and Succulent Greenhouse "Brilho do Sol", in Cianorte PR Brazil (2339'48' 'S; 58 36'18' 'W). One of the two plants donated was a five-year-old plant and the other was a two-year-old plant, both greenhouse cultivations. The plants had no visible stains or wounds. For isolation, the leaves were washed with distilled water in a $0.1 \%$ Tween 80 solution to remove dust particles. The material was superficially disinfected in a laminar airflow chamber using 70\% alcohol solution for $1 \mathrm{~min}$, $3 \%$ sodium hypochlorite for $2 \mathrm{~min}, 70 \%$ alcohol for $30 \mathrm{~s}$, followed by two rinses with autoclaved distilled water. A 100 $\mu \mathrm{L}$ aliquot of the water from the last rinse was seeded on TSA medium (Tryptic Soy Agar) as disinfection control.

Fragments of the disinfected leaves, measuring $5 \times 5 \mathrm{~mm}$, were macerated in Tryptone Soy Broth (TSB) medium and subsequently agitated at $150 \mathrm{rpm}$, for 12 hours, at $28^{\circ} \mathrm{C}$. Further, $10^{-1}$ and $10^{-2}$ suspensions were carried out in a $0.85 \%$ saline solution, sowing them $(100 \mu \mathrm{L})$ on TSA medium, supplemented with $50 \mu \mathrm{g} \mathrm{mL}^{-1}$ of a commercial fungicide. All plates were incubated for $72 \mathrm{~h}$, at $28^{\circ} \mathrm{C}$.
The concentration of the endophytes per gram of fresh plant tissue was calculated by the number of colonies observed in each dilution. All isolated bacteria were gram stained. Isolates were preserved in $25 \%$ glycerol and kept at $-80^{\circ} \mathrm{C}$

\section{In vitro antagonism against pathogenic fungi}

The phytopathogenic fungi Fusarium solani and Colletotrichum sp. retrieved from the Collection of Endophytes and Microorganisms of the Environment (CMEA) of the Microbial Biotechnology Laboratory of the Universidade Estadual de Maringá (UEM), Maringá PR Brazil, were used. The in vitro antagonistic evaluation of 40 endophytic bacteria was carried out in triplicate, following methodology by Specian et al. (2016). The inhibition index (Im\%) was evaluated by measuring the mycelial growth area of the phytopathogen with ImageJ $\mathrm{v}$ 1.46r software, following Oliveira et al. (2020).

\section{Inorganic phosphate solubilization index (SI) and} production of exopolysaccharides (EPS)

A $5 \mu \mathrm{L}$ aliquot of a suspension adjusted in a $0.85 \%$ saline solution on the $0.5 \mathrm{McF}$ arland scale of each endophyte was transferred to equidistant points on a Petri dish containing insoluble phosphate medium $\left(10 \mathrm{~g} \mathrm{~L}^{-1}\right.$ glucose; $5 \mathrm{~g} \mathrm{~L}^{-1}$ $\mathrm{NH}_{4} \mathrm{Cl} ; 1 \mathrm{~g} \mathrm{~L}^{-1} \mathrm{MgSO}_{4} .7 \mathrm{H}_{2} \mathrm{O} ; 0.8 \mathrm{~g} \mathrm{~L}^{-1} \mathrm{CaHPO}_{4} ; 15 \mathrm{~g} \mathrm{~L}^{-1}$ Agar; $\mathrm{pH}$ 7.2). Solubilization index (SI) was evaluated by measuring the size of the colorless halo formed around the bacterial colony/ by the colony size. The assay was done in triplicate for all endophytes and the plates incubated for 5 days at $28^{\circ} \mathrm{C}$.

Isolates were evaluated for EPS production as described by Kavamura et al. (2013) (20 g yeast extract; $15 \mathrm{~g} \mathrm{~K}_{2} \mathrm{HPO}_{4}$; $0.2 \mathrm{~g} \mathrm{MgSO}_{4} ; 0.015 \mathrm{~g} \mathrm{MnSO}_{4} ; 0.015 \mathrm{~g} \mathrm{FeSO}_{4} ; 0.03 \mathrm{~g} \mathrm{CaCl}_{2}$; $0.015 \mathrm{~g} \mathrm{NaCl} ; 15 \mathrm{~g}$ Agar, and then $10 \%$ of the carbon source, sucrose, at $\mathrm{pH} 7.3$ ) incubated at $28^{\circ} \mathrm{C}$, for five days.

\section{Biological nitrogen fixation assay}

Test tubes containing semi-solid $\mathrm{Nfb}$ medium without nitrogen $\left(5 \mathrm{~g} \mathrm{~L}^{-1}\right.$ Malic acid; $0.5 \mathrm{~g} \mathrm{~L}^{-1} \mathrm{~K}_{2} \mathrm{HPO}_{4} ; 0.2 \mathrm{~g} \mathrm{~L}^{-1}$ $\mathrm{MgSO}_{4} .7 \mathrm{H}_{2} \mathrm{O} ; 0.1 \mathrm{~g} \mathrm{~L}^{-1} \mathrm{NaCl} ; 0.02 \mathrm{~g} \mathrm{~L}^{-1} \mathrm{CaCl}_{2} .2 \mathrm{H}_{2} \mathrm{O} ; 2 \mathrm{~mL}$ micronutrient solution; $2 \mathrm{~mL}$ blue bromothymol solution; 4 $\mathrm{mL} 4 \mathrm{M}$ Fe EDTA; $1 \mathrm{~mL}$ vitamin solution; $4,5 \mathrm{~g} \mathrm{~L}^{-1} \mathrm{KOH}$, $1.8 \mathrm{~g} \mathrm{~L}^{-1}$ Agar; $1000 \mathrm{~mL}$ distilled water, $\mathrm{pH}$ 6.8) were used to detect biological nitrogen fixation. Bacteria were adjusted on the McFarland 0.5 scale and $2 \mu \mathrm{L}$ aliquots of the adjusted bacterial culture were transferred to test tubes with $\mathrm{Nfb}$ medium. They were incubated at $28^{\circ} \mathrm{C}$, for 72 hours. After this period, the appearance of a growth film near the surface of the tubes would indicate the ability to fix nitrogen.

\section{3-Indoleacetic acid (IAA) quantification}

Isolates were previously cultured in $10 \%$ TSB medium, supplemented with $5 \mathrm{mM}$ L-tryptophan, for three days, at 28 ${ }^{\circ} \mathrm{C}$, in the dark. Cultures were then centrifuged at $4000 \mathrm{rpm}$, for $10 \mathrm{~min}$. Further, $2 \mathrm{~mL}$ of Salkowski's Reagent were added in $1 \mathrm{~mL}$ aliquots of the supernatant, reacting for 30 min, in the dark, at room temperature. Qualitative analysis 
was verified by the colorimetric chemical reaction of oxidation of indolic compounds, with yellowish color for a negative and reddish-pink for a positive result. Readings for quantitative analysis were undertaken by spectrophotometer at a wavelength of $520 \mathrm{~nm}$, with normalization of readings using the standard curve $\mathrm{R}^{2}=0.9957$, obtained with different concentrations of the commercial standard of 3-indoleacetic acid (Sigma-Aldrich).

\section{Molecular identification of endophytic bacteria}

The amplification of the $16 \mathrm{~S}$ rRNA gene was performed using the colony PCR method. PCR reaction was performed with buffer (200 mM Tris-HCl, pH 8.4 - $500 \mathrm{mM} \mathrm{KCl),} \mathrm{dNTP}$ (2.5 mM), primers (Invitrogen $10 \mathrm{pMol}$ ) (PO27F: 5'GAGAGTTTGATCCTGGCTCAG-3' and R1378: 5'GGTGTGTACAAGGCCCGGGAACG-3'), Taq DNA polymerase $\left(5 \mathrm{U} \mathrm{mL}^{-1}\right), \mathrm{MgCl}_{2}(50 \mathrm{mM})$, autoclaved Milli-Q water, and $1 \mu \mathrm{L}$ of bacteria grown in TSB medium for 24 hours, at $28{ }^{\circ} \mathrm{C}$. PCR conditions, purification of amplicons, and phylogenetic analysis were performed according to Specian et al. (2016). PCR products were sequenced by ACTGene Análises Moleculares Ltda (Ludwigbiotec).

The obtained sequences were evaluated for quality by BioEdit v7.2.5 and subsequently submitted for chimera analysis using the DECIPHER Find Chimeras web tool (Specian et al., 2016). The sequences obtained were deposited in GenBank corresponding to the $16 \mathrm{~S}$ region (accession numbers: MW057773 to MW057775).

For the identification of the isolates, the nucleotide sequences were compared with those deposited at National Center for Biotechnology Information (NCBI) database using the BLASTn tool and applying the "sequences from type materials". Identification was based on the best value obtained for similarity.

Database sequences that showed high similarity with the obtained sequences were then retrieved and aligned for phylogenetic analysis, using ClustalW in the MEGA software (version 6.05) together with the isolates' sequences. The phylogenetic tree was undertaken by grouping with the neighbor-joining method, using p-distance for nucleotides with the option "the pairwise gap deletion" and bootstrap with 10.000 repetitions.

\section{Greenhouse assay}

The seeds of common and black beans were disinfected superficially according to the methodology described by Oliveira et al. (2020). Disinfected seeds were then immersed separately for $30 \mathrm{~min}$, without agitation, in suspensions of 0.2 optical density (adjusted in $0.85 \%$ saline solution at $600 \mathrm{~nm}$ on a spectrophotometer) of endophytes ELP06, ELG04 and ELG18. As control, the process was repeated by immersing seeds in $0.85 \%$ saline solution only.

Soil for the planting of seeds was prepared at 1:1 ratio (commercial Humus Fértil substrate: soil - collected at the Universidade Estadual de Maringá (2324'14.5"S; $\left.51^{\circ} 56^{\prime} 22.4^{\prime \prime} \mathrm{W}\right)$ and autoclaved at $121^{\circ} \mathrm{C}$, for $60 \mathrm{~min}$. Ten seeds were used in each treatment (ELP06, ELG04, ELG18, and control). They were transferred to 11 -size pots (height $7.5 \mathrm{~cm}$; upper diameter $10.7 \mathrm{~cm}$; lower diameter $7.5 \mathrm{~cm}$; volume 430 $\mathrm{mL}$ ), at a depth of $1 \mathrm{~cm}$, with one plant per pot, at a total of 40 seeds for common beans and 40 for black beans. All plants were kept under ambient conditions and the experiment was carried out for 30 days. The biometric parameters, such as plant height, number of leaves, roots length, and fresh/ dry shoot and root biomasses, were analyzed.

\section{Statistical analysis of the data}

All in vitro assays were carried out in triplicate. The greenhouse test was performed with 10 replicates for each treatment (treated and untreated plants). Data obtained for each experiment were analyzed statistically by analysis of variance (ANOVA) and the means compared by Scott-Knott test $(\mathrm{p}<0.05)$, using SISVAR 5.3.

\section{Results and Discussion}

Isolation by maceration methodology resulted in a colonization rate of $1.98 \times 10^{9} \mathrm{CFU} \mathrm{g}^{-1}$ for the two-year-old plant and $1.14 \times 10^{10} \mathrm{CFU} \mathrm{g}^{-1}$ for the five-year-old plant. There were 20 strains randomly selected for both plants, a total of 40 isolates. The classification of isolated endophytic bacteria as Gram stain and cell format are described in Supplementary Table S1.

Table S1 shows results for antagonistic activity, phosphate solubilization, biological nitrogen fixation, IAA quantification, and EPS production of $40 \mathrm{E}$. laui bacterial isolates. Considering these important activities for plantgrowth promoting agents, the endophytes ELP06, ELG04, and ELG18 were selected since they showed all activities and stand out as their ability to solubilize phosphate (ELP06 $3.44 \mathrm{~cm}$, ELG04 $2.93 \mathrm{~cm}$, and ELG18 $2.83 \mathrm{~cm}$ ), produce exopolysaccharides (ELP06 $16 \mathrm{~mm}$, ELG04 $18 \mathrm{~mm}$, and ELG18 $19 \mathrm{~mm}$ ), fix nitrogen and, especially, produce expressive amounts of IAA (ELP06 $76 \mu \mathrm{g} \mathrm{mL}^{-1}$, ELG04 46 $\mu \mathrm{g} \mathrm{mL}^{-1}$, and ELG18 $38 \mu \mathrm{g} \mathrm{mL}^{-1}$ ) when compared to the others strains evaluated (Table S1). These three endophytes were molecularly identified by DNA sequencing and investigated under greenhouse conditions in bean plants.

Figure 1 shows the dendrogram results from phylogenetic analysis. The analyses using BLASTn based on the sequencing of the 16S rRNA region for ELG04 (526 pb) and ELG18 (734 pb) showed 93\% similarity rate with the Pantoea dispersa species (GenBank code -AB907780.1) and grouped with $64 \%$ bootstrap with species $P$. dispersa in the phylogenetic analysis being confirmed at genus level as Pantoea sp. The endophyte ELP06 (677 pb), was also confirmed at genus level as Erwinia sp., showing $94 \%$ similarity rate with E. persicina (GenBank code $\mathrm{AB} 907778.1)$ and E. aphidicola (GenBank code AB907777.1), and 99\% bootstrap with E. aphidicola in the phylogenetic analysis (Figure 1). ELP06, ELG04, and ELG18 endophytes are bacillary gram-negative bacteria with yellowish pigmentation (Table S1).

In 1995, Stevens et al. (1995) suggested that Crassulaceae plants needed more scientific attention since few studies have been carried out for their biotechnological stance. After 25 years, this group of plants remains almost 
unexplored. In current research, endophytic bacteria from the E. laui plant, with two identified bacterial isolates belonging to the Pantoea and Erwinia genera were isolated and identified for the first time. The genus Pantoea comprises at the moment about 20 species generally reported as an endophytic, epiphytic or pathogenic lifestyle (Walterson \& Stavrinides, 2015). As endophytes, bacteria from this group have already been described (Herrera, Grossi, Zawoznik \& Groppa, 2016; Comby, 2017).

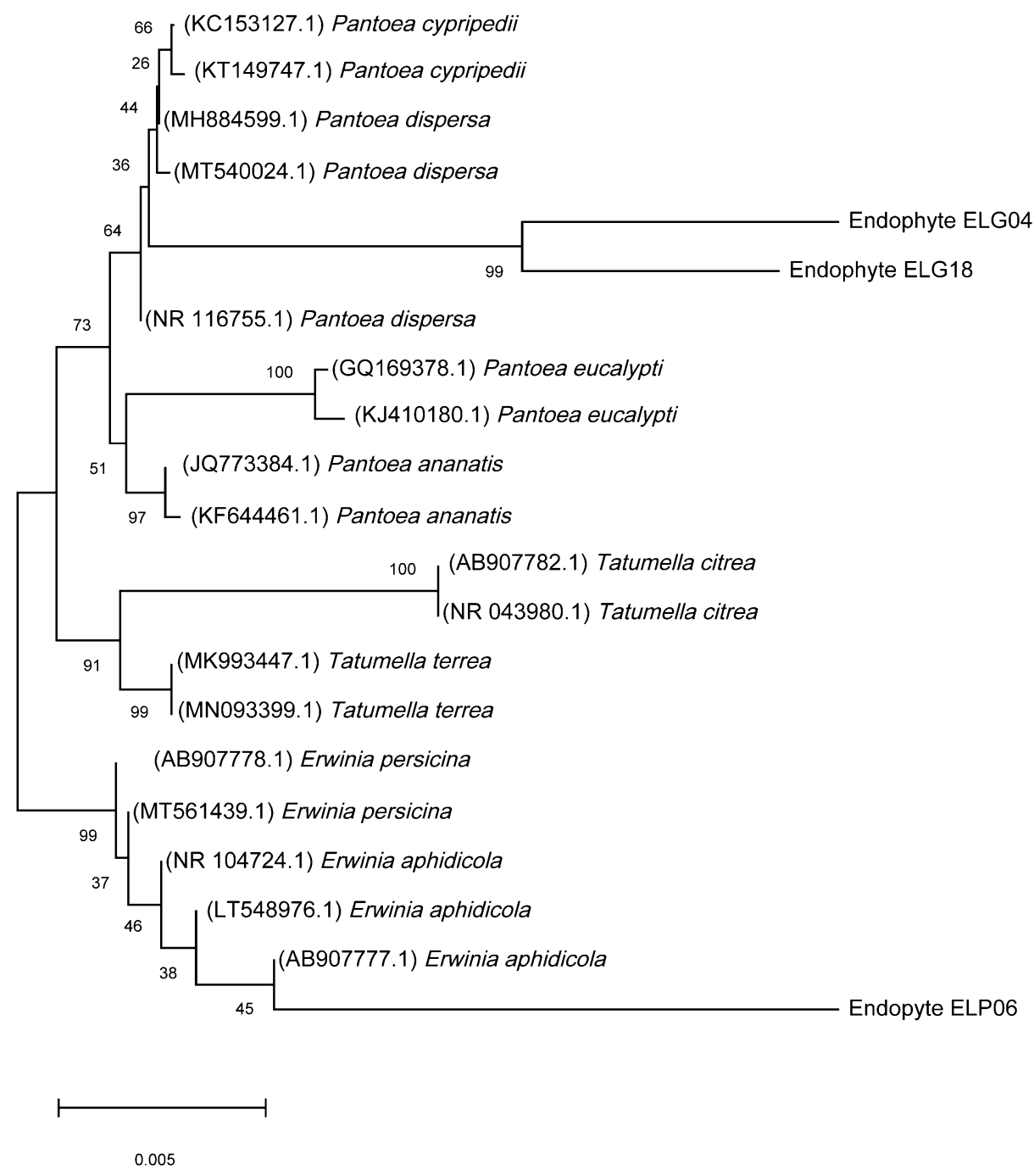

Figure 1. Dendogram results from the phylogenetic analysis based on the 16S rRNA region of the endophytic bacteria isolated from $E$. laui, built by the neighbor-joining method with p-distance for nucleotides and pairwise gap-deletion. The numbers represent the percentage of times that the isolates were grouped in the same node during the evaluation (bootstrap with 10.000 replications).

In the antagonistic activity against $F$. solani, 37 isolates stood out statistically, grouping with control, against the commercial fungicide $(39.40 \%)$. Strains ELP06 (51\%) and ELP17 (38.4\%) had the highest inhibitory rates (Figure S1). For the phytopathogen Colletotrichum sp., the isolates were not very efficient against the commercial fungicide $(43.40 \%)$ when compared to control.

Several endophytes may antagonize phytopathogens. Herrera et al. (2016) evaluated the antagonistic activity of $P$. agglomerans isolated from wheat and also reported the in vitro inhibition activity of this endophyte against a pathogenic Fusarium strain. Comby (2017) reports antagonism rates ranging between 13 and $16 \%$ for two pathogenic strains of Fusarium against an endophytic bacterium of the genus
Pantoea. Results by the authors above and those in current research reinforce the idea that this genus of bacteria has potential for the biocontrol of pathogens, especially against Fusarium sp.

For phosphate solubilizing activity (Figure S2), seven endophytic bacteria such as ELP06 (3.44 mm), ELG24 (3.43 $\mathrm{mm}$ ), ELP30 (3.42 mm), ELP30 (3.42 mm), ELP29 (3.39 $\mathrm{mm})$, ELG25 (3.34 $\mathrm{mm})$ and ELP26 (3.29 $\mathrm{mm})$ showed significant statistical results. In the in vitro biological nitrogen fixation, $80 \%$ of the bacteria showed a positive and $20 \%$ negative result. Several bacteria species from the Enterobacteriaceae and Erwinaceae families, such as those of the genus Pantoea and Erwinia, could play the role of a growth-promotion plant, helping them in the solubilization of 
this micronutrient. Collavino et al. (2010) evaluated the solubilizing capacity of this group of bacteria in in vitro and in vivo conditions and obtained promising results in the development of the common bean. Abreu et al. (2017) detected solubilization rates between $1.55 \mathrm{~cm}$ and $2.06 \mathrm{~cm}$, or rather, results similar to those in current study.

In the case of the activity of EPS production, ELP28 isolate was prominent with $25.66 \mathrm{~mm}$, followed by ELP17 $(22.33 \mathrm{~mm})$, ELP26 $(21.66 \mathrm{~mm}), \operatorname{ELP} 35(21.33 \mathrm{~mm})$ and ELG20 (20.66 mm) (Table S1). EP25 isolate had a halo of $37.66 \mathrm{~mm}$, this was considered a negative result since the medium was cloudy in its evaluation of precipitation with ethyl alcohol (Figure S3). The literature shows strains of the genus Pantoea as positive producers of exopolysaccharides (Niknezhad, Morowvat, Darz, Iraji \& Ghasemi, 2018), reinforcing the results in current research.

In the evaluation of IAA production, 39 isolates presented different concentrations of IAA, with emphasis on ELP06 (76.32 $\left.\mu \mathrm{g} \mathrm{mL}^{-1}\right)$, ELG04 (46.69 $\left.\mu \mathrm{g} \mathrm{mL}^{-1}\right)$ and ELG30 (49.73 $\left.\mu \mathrm{g} \mathrm{mL}{ }^{-1}\right)$. ELG01 strain failed to produce IAA under the conditions employed. Microbes from the Enterobacteriaceae family are also described as positive IAA-producers, as exemplified by Mishra (2011) and Silini-Chérif (2012).

All endophytes demonstrated positive and statistically significant results for the evaluated biometric parameters of the bean plants (Table 2 and Table 3). In the case of the common bean plants, the endophyte Pantoea sp. ELG04 was conspicuous for the fresh shoot weight when compared to control plants and other treatments. Analyzing the dry shoot weight, Pantoea sp. ELG18 and Erwinia sp. ELP06 showed statistically significant differences when compared to control. All endophytes stood out statistically for dry root weight when compared to control plants (Table 1).

In the case of black bean plants, Erwinia sp. ELP06 stood out for dry root weight when compared to the control plants and other treatments with the other endophytes. There were also significant statistical differences for the length of the roots in the treatments with endophytes Pantoea sp. ELG18 and Erwinia sp. ELP06.

All plants treated with the three endophytes showed statistically significant differences when compared to control plants (Table 2).

Table 1. Evaluation of endophytic bacteria associated with Echeveria laui under greenhouse conditions in Phaseolus vulgaris (common bean) seedlings. The biometric parameters were evaluated 30 days after inoculation.

\begin{tabular}{cccccccc}
\hline Treatment & NF $^{1}$ & Height & RL $^{2}$ & FSW $^{3}$ & FRW $^{4}$ & DSW $^{5}$ & DRW $^{6}$ \\
\hline Control plants & $7.0 \pm 0.94^{\mathrm{a}}$ & $19.3 \pm 0.94^{\mathrm{c}}$ & $17.0 \pm 0.88^{\mathrm{a}}$ & $10.02 \pm 0.65^{\mathrm{b}}$ & $3.33 \pm 0.16^{\mathrm{a}}$ & $2.06 \pm 0.61^{\mathrm{b}}$ & $0.375 \pm 0.10^{\mathrm{b}}$ \\
Pantoea sp. ELG04 & $6.4 \pm 0.84^{\mathrm{b}}$ & $19.3 \pm 0.79^{\mathrm{c}}$ & $15.4 \pm 0.49^{\mathrm{a}}$ & $15.58 \pm 0.73^{\mathrm{a}}$ & $3.89 \pm 0.31^{\mathrm{a}}$ & $2.21 \pm 0.40^{\mathrm{b}}$ & $0.544 \pm 0.13^{\mathrm{a}}$ \\
Pantoea sp. ELG18 & $6.5 \pm 0.84^{\mathrm{b}}$ & $22.8 \pm 0.67^{\mathrm{b}}$ & $17.6 \pm 0.70^{\mathrm{a}}$ & $11.22 \pm 0.60^{\mathrm{b}}$ & $3.78 \pm 0.52^{\mathrm{a}}$ & $2.79 \pm 1.04^{\mathrm{a}}$ & $0.595 \pm 0.19^{\mathrm{a}}$ \\
Erwinia sp. ELP06 & $7.6 \pm 0.51^{\mathrm{a}}$ & $24.3 \pm 1.03^{\mathrm{a}}$ & $16.9 \pm 0.66^{\mathrm{a}}$ & $12.16 \pm 0.74^{\mathrm{b}}$ & $4.62 \pm 0.32^{\mathrm{a}}$ & $2.95 \pm 1.11^{\mathrm{a}}$ & $0.663 \pm 0.21^{\mathrm{a}}$ \\
\hline
\end{tabular}

Means of the ten replicates. Means followed by the same letter in column do not differ by the Scott-Knott test (p <0.05). ${ }^{1} \mathrm{NF}$ : Number of leaves; ${ }^{2} \mathrm{RL}:$ Root length (cm); ${ }^{3}$ FSW: Fresh shoot weight (g); ${ }^{4}$ FRW: Fresh root weight $(\mathrm{g}) ;{ }^{5} \mathrm{DSW}$ : Dry shoot weight $(\mathrm{g}) ;{ }^{6} \mathrm{DRW}$ : Dry root weight $(\mathrm{g})$.

Table 2. Evaluation of endophytic bacteria associated with Echeveria laui under greenhouse conditions in Phaseolus vulgaris (black bean) seedlings. The biometric parameters were evaluated 30 days after inoculation.

\begin{tabular}{cccccccc}
\hline Treatment & $\mathrm{NF}^{1}$ & Height & $\mathrm{RL}^{2}$ & $\mathrm{FSW}^{3}$ & FRW $^{4}$ & $\mathrm{DSW}^{5}$ & $\mathrm{DRW}^{6}$ \\
\hline Control plants & $5.7 \pm 0.67^{\mathrm{a}}$ & $31.5 \pm 0.36^{\mathrm{a}}$ & $15.9 \pm 0.56^{\mathrm{b}}$ & $10.25 \pm 1.07^{\mathrm{b}}$ & $3.24 \pm 0.25^{\mathrm{a}}$ & $1.55 \pm 0.55^{\mathrm{b}}$ & $0.651 \pm 0.31^{\mathrm{a}}$ \\
Pantoea sp. ELG04 & $5.8 \pm 0.42^{\mathrm{a}}$ & $31.3 \pm 0.63^{\mathrm{a}}$ & $15.2 \pm 0.64^{\mathrm{b}}$ & $13.02 \pm 0.66^{\mathrm{a}}$ & $3.29 \pm 0.25^{\mathrm{a}}$ & $1.89 \pm 0.60^{\mathrm{b}}$ & $0.609 \pm 0.16^{\mathrm{a}}$ \\
Pantoea sp. ELG18 & $6.0 \pm 0.00^{\mathrm{a}}$ & $30.0 \pm 0.82^{\mathrm{a}}$ & $18.6 \pm 1.03^{\mathrm{a}}$ & $12.72 \pm 0.61^{\mathrm{a}}$ & $3.08 \pm 0.66^{\mathrm{a}}$ & $1.30 \pm 0.19^{\mathrm{b}}$ & $0.554 \pm 0.20^{\mathrm{a}}$ \\
Erwinia sp. ELP06 & $6.0 \pm 0.00^{\mathrm{a}}$ & $26.9 \pm 2.04^{\mathrm{a}}$ & $17.8 \pm 0.90^{\mathrm{a}}$ & $12.85 \pm 0.68^{\mathrm{a}}$ & $3.37 \pm 0.53^{\mathrm{a}}$ & $2.75 \pm 1.64^{\mathrm{a}}$ & $0.675 \pm 0.05^{\mathrm{a}}$
\end{tabular}

Means of the ten replicates. Means followed by the same letter in column do not differ by the Scott-Knott test ( $<<0.05)$. ${ }^{1}$ NF: Number of leaves; ${ }^{2}$ RL: Root length (cm); ${ }^{3}$ FSW: Fresh shoot weight $(\mathrm{g}) ;{ }^{4} \mathrm{FRW}$ : Fresh root weight $(\mathrm{g}) ;{ }^{5} \mathrm{DSW}$ : Dry shoot weight $(\mathrm{g}) ;{ }^{6} \mathrm{DRW}$ : Dry root weight $(\mathrm{g})$.

The inoculation of bacteria from Enterobacteriaceae and Erwinaceae families, such as Pantoea sp. and Erwinia sp., in plants of agronomic importance, have already been reported as beneficial for the treated plants and may contribute towards the development of their specific tissues, such as height/shoot or root system, as demonstrated by Sergeeva et al. (2007), similarly to those found in current research (Tables 1 and 2), or even increase the plant's resistance to environmental stresses as drought-tolerance in wheat treated with a $P$. alhagi strain (Chen et al., 2017).

It is a well-known fact that endophyte-host interaction has several physiological, metabolic and genetic mechanisms involved which directly or indirectly induce these microorganisms to not only compete for colonization but also to maintain it (Guo et al., 2008). This fact suggests that, due to this competition between endophytes, there would be a difference in these microorganisms in the development of their host, varying according to the colonized tissue and its age. López-González et al. (2017) studied the richness, diversity, and biological activity of endophytes associated with leaves of lima beans at different ages. Although results showed that the age of the tissue affects the endophytes' diversity and richness, it does not interfere negatively in the antagonistic potential of the isolated endophytes. Results by López-González et al. (2017) reinforce the findings of 
current research work, in which there were no significant differences in in vitro (Table S1) and in vivo (Table 1 and 2) activities of the endophytic bacteria isolated from a two-yearold and a five-year-old $E$. laui plants.

Another relevant point is the specificities of the plantendophyte. Oliveira et al. (2020) studied endophytes isolated from passion fruit and inoculated an endophyte in bean plants. These authors report that there were no symptoms of disease in the treated plants and suggested an endophytic association with the common bean, in the same way as with its original host. These findings strengthen the idea that endophytes could be associated endophytically with other plants than those of their origin, such as plants of agronomic interest as beans, similar to the Oliveira et al. (2020) study and current research.

\section{Conclusion}

In this work, we reported for the first time the isolation and identification of endophytic bacterial isolates associated with the E. laui plant. The in vitro assays to investigate the capabilities of these endophytic bacteria for plant-growth promoting agents have demonstrated that they have the ability to solubilize phosphate, produce IAA, antagonize phytopathogens (especially $F$. oxysporum), and produce EPS. Besides, $80 \%$ of endophytic bacteria showed the ability to fix nitrogen.

Under greenhouse conditions, the endophytes Erwinia sp. ELP06, Pantoea sp. ELG04, and Pantoea sp. ELG18 showed statistically significant results for promoting the growth of black and common bean plants with positive results on the height, root length, and biomass of the analyzed plants. Furthermore, endophytes from young (two years) and aged (five years) plants showed no differences with regard to biotechnological potential in the tests performed. Thus, these endophytes could be investigated for their ability to biocontrol against other phytopathogens, and for the interaction of these bacteria with other cultivars of agronomic importance aiming at the formulation of new agricultural eco-friendly inoculants.

\section{References}

Abreu, C.S., Figueiredo, J.E.F., Oliveira, C.A., Dos Santos, V.L., Gomes, E.A., Ribeiro, V.P., Barros, B.A., Lana, U.G.P., \& Marriel, I.E. (2017). Maize endophytic bacteria as mineral phosphate solubilizers. Genetics and Molecular Research, 16(1), 1-13. doi: 10.4238/gmr16019294.

Adhikari, P., \& Pandey, A. (2019). Phosphate solubilization potential of endophytic fungi isolated from Taxus wallichiana Zucc. roots. Rhizosphere, 9, 02-09. doi: 10.1016/j.rhisph.2018.11.002.

Bezerra, J.D., Azevedo, J.L., \& Souza-Motta, M.C. (2017). Why study endophytic fungal comunity associated with Cacti species?. In: Azevedo, J.L., \& Quecine, M.C. (Eds). Diversity and benefits of microorganisms from the tropics. Springer, p.21-36. doi: 10.1007/978-3-319-55804-2_2.

Breda, F.A.F., Alves, G.C., \& Reis, V.M. (2016). Productivity of mize in the presence of nitrogen levels and inoculation with Herbaspirillum seropedice. Pesquisa Agropecuária Brasileira, 51(1), 45-52. doi: 10.1590/S0100-204X2016000100006.

Chen, C., Xin, K., Liu, H., Cheng, J., Shen, X., Wang, Y., \& Zhang, L. (2017). Pantoea alhagi, a novel endophytic bacterium with ability to improve growth and drought tolerance in wheat. Scientific Reports, 7,41564. doi: $10.1038 /$ srep41564.

Collavino, M.M., Sansberro, P.A., Mroginski, L.A., \& Aguilar, O.M. (2010). Comparison of in vitro solubilization activity of diverse phosphatesolubilizing bacteria native to acid soil and their ability to promote
Phaseolus vulgaris growth. Biology and Fertility Soils, 46, 727-738. doi: doi: 10.1007/s00374-010-0480-x.

Comby, M., Gacoin, M., Robineau, M., Rabenoelina, F., Ptas, S.,Dupont, J., Profizi, C., \& Baillieu, F. (2017). Screening of wheat endophytes as biological control agents against Fusarium head blight using two different in vitro tests. Microbiological Research, 202, 11-20. doi: 10.1016/j.micres.2017.04.014.

Godeau, G., Laugier, J.P., Orange, F., Godeau, R.P., Guittard, F., \& Darmanin, T. (2017). A travel in the Echeveria genus wettability's world. Applied Surface Science, 411, 291-302. doi: doi: 10.1016/j.apsusc.2017.03.192.

Guo, L.D., Huang, G.R., \& Wang, Y. (2008). Seasonal and tissue age influences on endophytic fungi of Pinus tabulaeformis (Pinaceae) in the Dongling Mountains, Beijing. Journal of Integrative Plant Biology, 50(8), 997-1003. doi: 10.1111/j.1744-7909.2008.00394.x.

Herrera, S.D., Grossi, C., Zawoznik, M., \& Groppa, M.D. (2016). Wheat seeds harbour bacterial endophytes with potential as plantgrowth promoters and biocontrol agents of Fusarium graminearum. Microbiological Research, 187, 37-43. doi: 10.1016/j.micres.2016.03.002.

Jo, H., Jang, M., Hong, J.K., \& Parque, C.J. (2018). First report of fungal leaf spot in Echeveria spp. caused by Cladosporium tenuissimum in Korea. Plant Desease, 102 (7), 1450. doi: 10.1094/PDIS-08-17-1277PDN.

Kavamura, V.N., Santos, S.N., Silva, J.L., Parma, M.M., Ávilla, L.A., Visconti, A., Zucchi, T.D., Taketani, R.G., Andreote, F.D., \& Melo, I.S. (2013). Screening of Brazilian cacti rhizobacteria for plant growth promotion under drought. Microbiological Research, 168(4), 183-191. doi: 10.1016/j.micres.2012.12.002.

López-Ângulo, G., Montes-Avila, J., Díaz-Camacho, S.P., Veja-Aviña, R., Báez-Flores, M.H, \& Delgardo-Vargas, F. (2016). Bioactive components and antimutagenic and antioxidant activities of two Echeveria DC. species. Industrial Crops and Products, 85, 38-48. doi: 10.1016/j.indcrop.2016.02.044.

López-Gonzáles, R.C., Gómez-Cornelio, S., La Rosa-García, S.C., Garrido, E., Oropeza-Mariano, O., Heil, M., \& Partida-Martínez, L.P. (2017). The age of lima bean leaves influences the richness and diversity of the endophytic fungal community, but not the antagonistic effect of endophytes against. Colletotrichum lindemuthianum. Fungal Ecology, 26, 1-10. doi: 10.1016/j.funeco.2016.11.004.

Ma, Y., Oliveira, R.S., Nai, F., Rajkamar, M., Luo, Y., Rocha, I., \& Freitas, H. (2015). The hyperaccumulator Sedum plumbizincicola harbors metal-resistant endophytic bacteria that improve its phytoextraction capacity in multi-metal contaminated soil. Journal of Environmental Management, 156, 62-69. doi: 10.1016/j.jenvman.2015.03.024.

Mishra, A., Chauhan, P.S., Chaudhry, V., Tripathi, M., \& Nautiyal, C.S. (2011). Rhizosphere competent Pantoea agglomerans enhances maize (Zea mays) and chickpea (Cicer arietinum L.) growth, without altering the rhizosphere functional diversity. Antonie van Leeuwenhoek, 100, 405-413. doi: 10.1007/s10482-011-9596-8.

Neetha, J.N., Sandesh, K., Kumar, K.G.., Chidamamda, B., \& Ujwal, P. (2019). Optimization of Direct Blue-14 dye degradation by Bacillus fermus (Kx898362) an alkaliphilic plant endophyte and assessment of degraded metabolite toxicity. Journal of Hazardous Materials, 364, 742-751. doi: 10.1016/j.jhazmat.2018.10.074.

Niknezhad, S.V., Morowvat, M.H., Darz, G.N., Iraji, A., \& Ghasemi, Y. (2018). Exopolysaccharide from Pantoea sp. BCCS 001 GH isolated from nectarine fruit: production in submerged culture and preliminary physicochemical characterizations. Food Science and Biotechnology, 27(6), 1735-1746. doi: 10.1007/s10068-018-0409-y.

Oliveira, J.A., Polli, A.D., Polonio, J.C., Orlandelli, R.C., Conte, H., Azevedo, J.L., \& Pamphile, J.A. (2020). Bioprospection and molecular phylogeny of culturable endophytic fungi associated with yellow passion fruit. Acta Scientiarum Biological Sciences, 42, 1-11. doi: 10.4025/actascibiolsci.v42i1.48321.

Sánchez-Cruz, R., Vázquez, I.T., Batista-Garcia, R.A., Méndez-Santiago, E.W., Sánchez-Carbente, M.R., Leija, A., Lira-Ruan, V. Hernández, G., Wong-Villarreal, A., \& Folch-Mallol, L. (2019). Isolation and characterization of endophytes from nodules of Mimosa pudica with biotechnological potential. Microbiological Research, 218, 76-86. doi: 10.1016/j.micres.2018.09.008. 
Sergeeva, E., Hirkala, D.L.M., \& Nelson, L.M. (2007). Production of indole3-acetic acid, aromatic amino acid aminotransferase activities and plant growth promotion by Pantoea agglomerans rhizosphere isolates. Plant Soil, 297, 1-13. doi: 10.1007/s11104-007-9314-5.

Silini-Chérif, H., Silini, A., Ghoul, M., \& Yadav, S. (2012). Isolation and characterization of plant growth promoting traits of a rhizobacteria: Pantoea agglomerans Ima2. Pakistan Journal of Biological Sciences, 15(6), 267-276. doi: 10.3923/pjbs.2012.267.276.

Stevens, J.F., Hart, H., Ham, R.C.H.J., Elema, E.T, Van Den Ent, M.M.V.X., Wildeboer, M., \& Zwaving, J.H. (1995). Distribution of Alkaloids and Tannins in the Crassulaceae. Biochemical Systematics and Ecology, 23(2), 157-165. doi: 10.1016/0305-1978(95)00082-6.

Walterson, A.M., \& Stavrinides, J. (2015). Pantoea: insights into a highly versatile and diverse genus within the Enterobacteriaceae. FEMS Microbiology Reviews, 39(6), 968-984. doi: 10.1093/femsre/fuv027.

License: Creative Commons CC BY 4.0

This article was published with open access for distribution under the terms of the Creative Commons Attribution License, which allows unrestricted use, distribution, and reproduction in any medium, provided the original work is properly cited. 